\title{
The Fateful Adventures of the Good Soldier Bauman. An Appreciation of Zygmunt Bauman (1925-2017)
}

\author{
DENNIS SMITH*
}

Osudy dobrého vojáka Baumana. Pocta Zygmuntu Baumanovi (1925-2017)

\begin{abstract}
Zygmunt Bauman was a man of action, a brilliant persuader, and a stern moralist. As a young communist he acted with sincerity on the maxim that an omelette cannot be made without breaking eggs. He was shocked to discover, twice, in 1953 and 1968, that he was one of the eggs being broken. This paper reviews his subsequent migration West and his career as a public intellectual in the light of these early experiences. His attempt to forge a Marxist sociology, or a sociological Marxism was abandoned after what he believed was the victory of global capitalism, especially after 1989-91. Bauman then devoted his energies to elaborating and adapting themes derived, in part, from Adorno, Arendt and Marx, attuning them to a culture of 'post-modern' (later 'liquid') existence organized as an exercise in mass seduction rather than mass destruction. He was always something of a stranger in the West but he sought to persuade his audience that this condition was universal, a product of capitalist globalization. He established himself as a widely admired guide to the resulting moral and political challenges. Till the end he worried away at the issue of how to achieve and combine moral probity and political effectiveness.
\end{abstract}

Keywords: Zygmunt Bauman; Poland; communism; Marxism; morality; liquid modernity; post-modernity; Ernst Gellner; estrangement

DOI: $10.14712 / 23363525.2017 .20$

\section{From East to West}

We have recently lost Zygmunt Bauman (1925-2017) at the age of ninety-one. He became a global figure. One small piece of evidence confirming the global dimension of his reputation is a request I got shortly after he died from a reporter with the Beijing Daily News who invited me to do an email interview about Bauman. ${ }^{1}$

In the interview I commented that Bauman had been not just a sociologist but also a philosophizer, a moralist and a captivating storyteller for our times. I recalled that in the mid 1970s when I was a sprightly thirty year old I gave a talk at a seminar in Leeds. There was a man sitting quietly on a chair near the door, not joining in. He was fifty-ish, not overly tall, wearing a smart dark suit. His hair was short, dark and receding. When my talk was over he came over and with quiet dignity thanked me for coming and said that he had found the talk very interesting. This was my first encounter with Bauman.

It was twenty years before we met again. I contributed to a celebration of Bauman's life and work that was arranged at Leeds University shortly after his seventieth birthday. My

Prof. Dennis Smith, Department of Social Science, Brockington Building, Loughborough University, Loughborough Leicestershire LE 11 3TU, Unitet Kingdom. E-mail: d.smith@lboro.ac.uk.

1 The Beijing News Book Review, interview with Dong Luo, 14th January 2017. For a slightly revised English version see http://www.academia.edu/30932959/Zygmunt_Bauman_Morality_Monsters_Metaphors_and _Marx_January_2017 [accessed 1st February 2017]. 
third and last personal encounter with him was a couple of years later, shortly after I got a book contract to do a study of his work [see Smith 1998; Smith 1999]. I went to see Bauman in his house at Leeds. Bauman showed me the office where he did his writing ('This is where it all happens'), and we went off to the pub in his car to have lunch.

The Bauman I met in the late 1990s had a very different style from the one I saw two decades earlier. His hair was white and a little unruly. His face was highly mobile. His hands were rarely far away from his pipe, which he would puff sagely. He was full of thoughts. However, I was also aware of an inner lock gate, sometimes holding back and sometimes releasing the mental torrent. The pipe was, perhaps, a useful device for gaining time to calibrate and control the inner flow of thought. When Bauman was in situations where he, so to speak, controlled the whole show, whether at his keyboard or on the platform, he was like a pedigree sheepdog bounding round the field, rounding up his arguments and driving them into the pen, showing off his speed and agility, thoroughly enjoying the chase.

I do not think the Bauman I met in the mid-1970s and the other manifestation I encountered two decades later were, respectively, the 'younger' and the 'older' Bauman. Instead, I reckon they were both ever-present, two sides of Bauman, sometimes on display, sometimes not. By all accounts, the effervescent, charismatic version of Bauman was often on show in Warsaw during the 1960s.

Some of Bauman's essays from the 1960s [such as Bauman 1966] suggest that very early in his intellectual career he had already arrived at the basis understanding of the human condition with which he has been strongly associated in recent years. His analysis proceeds as follows. The old sources of authority - gods, priests, elders, monarchs, aristocrats, state bureaucrats and even the voice of 'the people' - have lost their legitimacy. We each now have to make our life choices without any external guidance. These choices often have a profound moral dimension, including harm done and good left undone. Most people cannot cope with such responsibility so this enormous moral challenge is very often sidestepped. Instead we bow down before confidently assertive bureaucrats, who impose, often unreflectively, rules handed down 'from above'. The upshot is that the modern world is, morally speaking, 'running on empty'. In other words, it is not sufficiently well fuelled by a deep ethical sense that allows individuals to work out for themselves whether their own rule-following behaviour is moral or immoral.

For his part, Bauman insisted that acting or failing to act was itself always the expression of a personal choice with an inescapable moral dimension. He recommended that every individual should awaken their conscience, giving the other's needs priority over their own selfish materialistic desires. In fact, the problem was not simply untrammeled personal greed. Bauman lived through the 1970s and 1980s when the people were, so to speak, driven out of the forums of civic debate, which were being shut down or at least starved of business by privatization, and shepherded into glittering shopping malls that offered a multitude of glamorously advertised diversions.

This before/after contrast was exacerbated by Bauman's migration from socialist Poland to the capitalist West. When these dynamic impressions had settled down, he came to the lasting conclusion that modern life was plagued by two structuring mechanisms: on the one hand, bureaucracies determined to impose their control over the world around them by the relentless categorization of people and things; and, on the other hand, capitalist big business with its relentless pursuit of profit through the market. 
Before migrating to the capitalist world Bauman had already traversed many new frontiers: moving in 1939 from Nazi-threatened Poland to the Soviet Union then in full mobilization mode; entering Berlin, then Warsaw with the Polish units attached to the Red Army in 1945; venturing into the risky wilderness of revisionist Marxism during the 1960s; to Israel briefly; then during the 1970s installing himself in the strange venues haunted by his old party's official enemy, the West.

Bauman's early years in the military made him and marked him. They gave him rapid promotion and superb self-confidence, then shattered it when he was dishonourably discharged in 1953, aged 28. This sort of exhilarating but ultimately disastrous roller-coaster ride was a common pattern for people in that line of work at that time and place. It severely tested personal resilience. For his part, Bauman had plenty of bounce and ambition. He decided to remake his career and, if possible, help reform the (as he then realized) corrupt, confused and inadequate Communist institutions that had failed him.

In his personal campaign to escape the clutches of Communist orthodoxy, the revisionist Bauman, by now an academic, found some of the intellectual sustenance he needed in American sociology, especially its radical tradition. This was cultivated by C. Wright Mills but also lurked deep within the Chicago School, for example in the work of scholars such as Louis Wirth on urban estrangement [e.g. Wirth 1938] and W. I. Thomas on migrating Poles [in Thomas - Znaniecki 1918-20], a group to which Bauman would shortly belong.

In fact, a large part of Bauman's achievement was to revise for a new era the evocations of exploitative capitalism and alienating bureaucracy initially offered between the wars by the Frankfurt School in Europe and by the Chicago School in America. Their interwar transatlantic visions focused on the destruction and exploitation of human lives in local communities, engineered by wealthy and powerful interests in societies that worshipped strength and success. Bauman refashioned those visions for a post Cold War era, one in which overt exploitation is replaced by cynical seduction at the hands of big business and the government. There is much talk of equality and justice but widespread neglect of the human interests of those who are poor, weak and failing. When we are confronted by such evils, Bauman urges us to be clear-sighted, self-aware and morally responsible.

Later, during the 1990s, Bauman besieged and captured the castle of post-modernity, which he occupied and made his own. In the 2000s he vacated this castle and tried his luck in the surrounding moat, or rather, as he preferred to see it, the all-encompassing ocean of liquid modernity. He was still swimming there when his time finally ran out.

In true pioneer tradition Bauman died with his boots on. He was writing and publishing till the end. Four new titles appeared in 2016, and another early in $2017 .{ }^{2} \mathrm{He}$ was then about two years into his second marriage. By 2017 Bauman had behind him a long and extraordinary career as a persuader, steering the thoughts and actions of others and exercising leadership and command in many situations: on the battlefield, in military and political campaign headquarters, in academic departmental meetings, in lecture rooms and conference halls, and in letters, emails and interviews.

2 For an up to date and comprehensive bibliography of books by and about Zygmunt Bauman, see the following: http://www.sociosite.net/sociologists/bauman_zygmunt.php [accessed 1st February 2017]. 
Bauman was such a quick thinker, talker and reader, and had accumulated such a wealth of knowledge and experience that he usually had little difficulty in doing two things: persuading his audiences that they had grasped only half-truths about the world; and showing them that he had a bunch of keys that would unlock at least some of the mysteries they were confronting and give them a greater sense of clarity.

\section{Two Missions, Two Trilogies}

Bauman was at the height of his powers between the early 1970s and the early 1990s when, primarily to satisfy his own intellectual, political, and moral curiosity, he used the freedom of being in the West to undertake two missions. The first was to work out how he could rescue, revise and reshape the most useful and powerful elements of the orthodox Marxist analysis he had learnt so arduously in his youth then instilled so assiduously into the heads of his soldierly charges during his early career years as a political officer in Warsaw.

When Bauman finally abandoned that project he sought instead to build upon the Enlightenment values that, in his view, stood at the centre of Marx's original conception of his world-shaking enterprise. This took him towards his second projected destination, moving him on from the delineation of a modern sociological Marxism towards the creation of a new sociology of post-modernity. These two missions led to the composition of two trilogies.

The first trilogy built upon the premise that sociologists should recognise that although human beings are embedded in constraining social structures they could also make choices and initiate social change. Bauman wanted sociology to become the means of undertaking an ambitious rational exploration of the world, emancipating human beings, making their lives better. This meant undermining the narrow claims of positivism, which restricts itself only to the measurable dimensions of the existing observable world. It also meant pushing aside the limited assumptions embodied in common sense views of what could and should be. Instead, sociology had to build upon and incorporate the insights of philosophers.

Sociology and sociologists had to maintain a healthy distance from state power and keep close to the people, making links with several different groups with diverse interests and opinions. But they should equally make sure that sociology did not merge with the tenets of common sense that prevailed in common parlance, since this risked reproducing half-truths and half-disguised prejudice. At the same time, it was important to avoid retreating into a realm of discourse that was so specialised and abstruse that it lost touch with the people's everyday experience.

These were the ideas that Bauman developed systematically in three interconnected works: Culture as Praxis [Bauman 1973], Towards a Critical Sociology [Bauman 1976b] and Hermeneutics and Social Science [Bauman 1978]. Two other books rounded out the argument made in the trilogy. In Between Class and Elite [Bauman 1972] Bauman paid tribute to the struggle for justice and equality of early leaders in Britain's labour movement. Later, in Socialism - the Active Utopia he opened his argument with the one-line assertion that 'Socialism descended upon nineteenth-century Europe as utopia' [Bauman 1976a], 9. Sounds familiar? Think Marx and Engels: 'A spectre is haunting Europe ...' 
Bauman's account of the past, present and future of socialist modernity likewise has an (implicit) co-author: Antonio Gramsci [see especially Bauman 1976a, chapter five].

A decade later, this first synthesis no longer satisfied Bauman, so he set off on another quest that produced the better-known trilogy that includes Legislators and Interpreters [Bauman 1987], Modernity and the Holocaust [Bauman 1989], and Modernity and Ambivalence [Bauman 1991]. In these works Bauman discovered some different ancestors, and a different historical myth. Instead of working-class heroes beating back against oppression, his forebears were now intellectuals, especially Jewish intellectuals, trying to cope with the irreducible ambiguity of modern culture.

Legislators and Interpreters traces the rise, fall and transformation of a distinctive status group, intellectuals who since the Enlightenment had been influential as educators in shaping the policies of emerging national states. But as the market's influence in societal management increased, the need for these intellectuals decreased. They were also marginalized by the spreading tentacles of official bureaucracy, which elbowed aside their ethical reservations, as Modernity and the Holocaust showed in an extreme demonstration of a universal tendency. Finally, Modernity and Ambivalence exhibited the intellectual trials of Jews such as Freud, Simmel and Kafka who struggled creatively to discover meaning and coherence in their lives and careers.

My main criticism of the two trilogies Bauman produced in these years is that he threw out the 'baby' of careful comparative-historical analysis with the 'bathwater' of historical materialism. The point is that Gramsci, Habermas and other theorists (and there were many in Bauman's stock cupboard) gave him handholds provided by politico-cultural analysis within neat all-encompassing abstract frameworks. Once he had grasped these handholds Bauman decided to kick away or ignore the contents of another stock cupboard: the one that contained the detailed empirical case studies that allow historians to build up their own picture of the past and present in advance of (or sometimes instead of) delving into theories that explain to them how things work even before they look into them.

In fact, Bauman did not simply present his studies in Gramscian, Habermasian, Foucauldian or other 'branded' frames. By the early 1990s he had learned to interweave in his work another lively element: the empirical evidence he garnered by drawing on observations of incidents in everyday life. That was where he discovered his 'intimations of postmodernity', for example.

This was the art of the flaneur, the relaxed wanderer who saunters through city streets, observing what is going on [for example, in Bauman 1992]. It was also the art of the photographer who takes pictures of scenes within the disorderly sequences of human activity and then pours over them in the studio, looking for interconnections and deeper significance. Not least, it is also the art of the police investigator or detective who pieces together a larger picture of social networks and group intentions by spotting a turned-up collar here, a discarded newspaper there, a rapid disappearance down a dark alley, or a whispered conversation in a quiet café. Bauman was familiar with this scenario. He had been there during his Warsaw days, on both sides, hunter and hunted.

This was the sociological world Bauman was investigating and inhabiting when I did my survey of his work and career in the late 1990s. In my book I did my own bit of constructive map-making, collating the scattered pictures created by Bauman of many parts 
of the territory through which he had been wandering, putting them together to produce a kind of rough guide. It was a plan of the castle of post-modernity that Bauman had captured and occupied a few years before, incorporating the intellectual refurbishments he had installed in the succeeding years [see Smith 1999: 136-166].

\section{Water-tight in a Liquid World}

By 2000, roughly a decade after beginning his experiments with intimations, fragments and other pointilliste preoccupations, Bauman had worked his way back to the big global picture. He clearly did not wish to be trapped inside any castle, even of his own devising, so he adopted a brilliant metaphor that allowed him to combine the flexibility of the flaneur with the global scope of the round the world sailor. He conveniently discovered that the world was liquid; so 'liquid modernity' was born. The only bit of the liquid world to which Bauman granted useful solidity was the European Union, which he seemed to see as a kind of Noah's Ark carrying humankind's hopes. Deep in the EU's hold was his precious Poland [see Bauman 1971; Bauman 2004].

From this point in his life and career, the reason that Bauman's work retains its fascination, for me at least, is not in the main because of what it tells us about the world, sociologically speaking, although he effectively deploys the pragmatic wisdom and ethical standards he has cultivated in the preceding half century. Instead, the work is interesting because of what it may seem to tell us (and the cautious language is deliberate) about Bauman himself. In fact, that was always the main interest for me, given my parallel inquiries into other contemporaries of the twentieth century and in some cases beyond, such as Hannah Arendt, Norbert Elias, Michel Foucault, Barrington Moore, Immanuel Wallerstein and others [explored in, for example Smith 1991; Smith 2000].

All these scholars have done work that helps to explain the world, and lived lives that help to explain their work. In some cases, their work may also help to illuminate the lives they have lived, located as they are at many different points on the geo-political scene, each dedicating themselves to unravelling the complexity of capitalist modernity. Knowing where these different writers are coming from helps us to triangulate their different perspectives.

Caution and patience is required on all fronts. For example, it was not until a couple of years ago that I discovered that the radical Barrington Moore, whom I initially researched for a book published in 1983, was brought up by a grandfather who was the attorney of the fabulously wealthy J. P. Morgan [Smith 2015]. Moore was put through an exclusive upper class education, and got bullied, but found solace, sustenance and, not least, a detached and strongly independent frame of mind, from his scholarly studies, especially in the classics.

Patience has also been a virtue in reflecting on the life of Zygmunt Bauman. In the original draft of my book on Zygmunt Bauman (this would be in the late 1990s) I referred to his friend, Stefan Morawski who reckoned that young Major Bauman, as he was in the early 1950s following a very 'good' war, could easily have been promoted to the rank of general [Morawski 1998]. I took the thought a little bit further and speculated that if Bauman had stayed in the military, instead of being dishonourably discharged in 1953, he might have ended up as national leader of the Polish republic; I was thinking of Jaruzelski, 
although I did not mention him. ${ }^{3}$ This speculation got the strongest reaction from Bauman of anything I ever wrote or said. He wrote back that I was completely wrong. It was an unthinkable idea. He was 'a terrible soldier' or words to that effect.

Looking back on those words, which I doubted but took at face value at the time, I am reminded of The Fateful Adventures of the Good Soldier Švejk [Hašek 1997], which, as everyone knows, is a hilarious satire of the First World War. Hašek's hero, Švejk, was indeed a terrible soldier, one who had no respect for his officers. The inventor of Švejk is definitely a man for our own times: goodbye Hayek, hallo Hasek.

He would no doubt recognize the burning resentment many voters in the age of Trump and Brexit seem to feel at the incompetence and lack of care for ordinary people displayed by their political masters. But is this what Bauman meant? Was that how he felt in the late 1940s and early 1950s? I am pretty sure that he did not. He was no Švejk. His approach was much more upbeat. For example, he fought in the battles of Kolberg and Berlin and at the end of the war was awarded Poland's Military Cross of Valour for bravery in the field. ${ }^{4}$

In this context it is interesting to notice that Zygmunt Bauman's second wife, Aleksandra Jasińska-Kania, whom he married in his late eighties, is the daughter of Boleslaw Bierut (1892-1956). This man was Poland's national president from 1947 to 1952, and then its prime minister from 1952 to 1954 . Bierut had a ferocious reputation. He was the man that organized the repression that the Kremlin and their subordinates in Warsaw thought was necessary to fasten Stalin's grip upon the population of Poland after the end of the Second World War [see Main 2004 and, for background, Applebaum 2013].

During Bierut's years of power Zygmunt Bauman became a senior officer of Poland's Internal Security Corps or 'internal army', with special responsibility for political education within the military. Documents apparently still in the archives suggest that Bauman was also for a while (1945-1948) registered as an underground informant for the regime. ${ }^{5} \mathrm{He}$ was a totally dedicated Communist, committed to making sure that soldiers imbibed the Kremlin-approved orthodoxy regarding how Poland should develop and how Poles should live and think. Two things seems clear: Bauman was both an efficient bureaucrat and a brave soldier.

As everybody knows, in 1953 Major Bauman was suddenly sacked. This happened shortly after his father had made an inquiry about migration at the Israeli embassy. It was also just five days after the death of Stalin. Bauman dyed his uniform a different colour and

3 Wojciech Witold Jaruzelski was born in 1923, two years before Bauman. In 1943 he joined a Polish military unit under Soviet control. He joined the Polish communist party in 1948 and like Bauman, became an informant. By 1960 he was the chief political officer of the Polish armed forces. By 1981 he was prime minister. See, for example, Berger 1990.

4 Sources include http://www.encyklopedia.naukowy.pl/Aleksandra_Jasińska-Kania; http://www.encyklopedia .naukowy.pl/Bolesław_Bierut; http://www.newsweek.pl/polska/corka-bieruta--procent-od--kapitalu-,99566,1,1 .html; Joshua Levitt, 'Jewish Professor Who Declined Honorary Polish Doctorate Because of Anti-Semitic Attacks is No Stranger to Discrimination', The Algemeiner 22nd August 2013 at https://www.algemeiner .com/2013/08/22/jewish-professor-who-declined-honorary-polish-doctorate-because-of-anti-semitic -attacks-is-no-stranger-to-discrimination/ [all accessed 1st February 2017], Mark Davis and Tom Campbell, 'Zygmunt Bauman obituary', Guardian 15th January 2017 at https://www.theguardian.com/education/2017 /jan/15/zygmunt-bauman-obituary [all accessed 1st February 2017].

5 See Aida Edemariam, 'Professor with a past'. Guardian 28th April 2007 at https://www.theguardian.com /books/2007/apr/28/academicexperts.highereducation [accessed 1st February 2017]. 
became a civilian. He made a second career as an academic, still a Marxist but now pursuing a dissident intellectual path. That second career also came to a sudden end in 1968 when he was denounced by the regime, along with other dissidents, as a highly undesirable person. This occurred as part of an anti-Semitic campaign sponsored by the government. Bauman and his family left Warsaw, initially for Israel, ultimately for Leeds.

Now fast forward four decades. By that time Bauman had filled a very long shelf with his new books and offprints and had a substantial number still to write. Then his wife Janina died in 2009 after what had been a very long and by all accounts, a very happy marriage. Six years later Bauman escaped from widowerhood by marrying Aleksandra Jasińska-Kania, his old boss's daughter. Bauman's new wife, born in 1932, had been one of his doctoral students. At that time she was, like him, interested in the way American sociology dealt with the theme of alienation. She also, like him, became a globe-trotting academic. Bauman's second marriage was also, clearly, a very happy one. ${ }^{6}$

The conclusion I tentatively draw is that Bauman retained throughout his life some sense of connection with the elite politico-academic circles that took shape in Warsaw during the 1950s and 1960s. Bauman was evidently an active and influential player in those circles where everyone was always vulnerable and the game could change very quickly. For over two decades as a young man in Warsaw Bauman was a confident and successful insider, first in the Polish military and then in the Polish academic world. It is surely the case that in both spheres he was deeply ambitious, pursuing influence and building up a constituency of supporters. However, in neither sphere was he ever secure. Indeed, in both cases he finally stumbled, then tumbled painfully, when the political climate changed more quickly than he could.

It seems to me probable that Bauman's two very public humiliations, in 1953 and 1968, were crucial learning experiences that shaped the rest of his life and career. By the late 1960s he was finished with Warsaw roulette. The cultural pastures of the commercialized West offered an arena with less overt nastiness, many charming publishers, and softer ground on which to fall. Once he had left Poland, found his way to Britain, and recovered his composure, so to speak, Bauman seems to have decided to transfer his competitive instinct fully to the sphere of the intellect. Henceforth, secure in his Leeds redoubt, he could engage in competition within the vast arena of the West. His principal opponent would be himself, pushing himself to the limit. This would be much less risky than a life of bitter score-settling back in the Polish capital.

Bauman evidently knew his way around Warsaw society from top to the bottom but my impression was that in Britain he found it difficult to absorb and adopt the native habitus. I remember once on the fringes of a conference strolling with him towards the lecture hall through a series of doors. He insisted on following a specific etiquette of door holding, taking turns. This was partly half-joking, but partly also, it seemed, due to feeling uncomfortable with too much British casualness or informality. Bauman was not, perhaps, fully at home except when he was, quite literally, at home, back in his pleasant Leeds house with his study, books and familiar domestic things.

6 Professor Aleksandra Jasińska-Kania is Professor Emerita of Sociology at Institute of Sociology at Warsaw University in Poland. She has researched on values, democracy, ethnic stereotypes, citizenship, national identity, and nationalism. 
Bauman never integrated himself into the British educational establishment as completely or successfully as, say, Ernest Gellner (Oxford, Edinburgh, LSE) his near-contemporary from the Czech Republic. Of course, Gellner had over thirty years start, having initially arrived in Britain in 1939. For his part, Bauman, who acquired a bit of a reputation as an authoritarian in his early days at Leeds, may well have shunned the prospect of the long committee meetings, bureaucratic battles and compromises that heading for the upper slopes entailed. In the West Bauman evidently preferred to be an interpreter rather than a legislator.

Add to this three other things: Bauman's absolute determination to follow his own chosen course, whatever that might be at any one time; his apparent need to be a visible success in every project he undertook (so that, for example, a sociology professor who knew Bauman well once told me that when Bauman first took up photography seriously he was soon entering photographic competitions and winning prizes); and, not least, his energetic efforts to impose upon his audience the standards by which he, Bauman, should be judged. An example of this last point is the way he repeatedly insisted that all men and women were deeply estranged. In fact, Bauman did something very remarkable. By getting his audiences to take seriously his notion that we are all strangers to one another, Bauman, so to speak, assimilated the entire population in the West and beyond to his own condition as an outsider. By accepting this analysis, his readers adopted and adapted to his view of the world. Bauman could therefore present himself not only as a stranger amongst strangers, but also as a self-declared expert on that condition. It was a way of integrating himself into Western society at large while maintaining a comfortable sense of distance due to the authority that his growing reputation for wisdom commanded.

By his last decade, Bauman had achieved a unique role as the world's moral weather forecaster. He continued to work tremendously hard. I suspect this was partly from a strong sense of duty; the good soldier ensuring that his audience had the best and most up-to-date analyses he could provide. Perhaps it was also residual anxiety left over from the falls he took in 1953 and 1968. He once told me that he was not troubled by political attacks that referred back to those times. He said he was 'water-tight'. That surely helped him feel safe in his own invented realm of liquid modernity.

\section{Bibliography}

Applebaum, Anne [2013]. The Crushing of Eastern Europe, 1944-1956. London: Penguin.

Bauman, Zygmunt [1966]. Three remarks on contemporary educational problems. Polish Sociological Bulletin 6: 77-89.

Bauman, Zygmunt [1971]. Social dissent in the East European political system. European Journal of Sociology 12: 25-51.

Bauman, Zygmunt [1972]. Between Class and Elite. Manchester: Manchester University Press.

Bauman, Zygmunt [1973]. Culture as Praxis. London: Routledge

Bauman, Zygmunt [1976a]. Socialism - the Active Utopia. London: Allen and Unwin.

Bauman, Zygmunt [1976b]. Towards a Critical Sociology. London: Routledge.

Bauman, Zygmunt [1978]. Hermeneutics and Social Science. London: Hutchinson.

Bauman, Zygmunt [1987]. Legislators and Interpreters. Cambridge: Polity.

Bauman, Zygmunt [1989]. Modernity and the Holocaust. Cambridge: Polity.

Bauman, Zygmunt [1991]. Modernity and Ambivalence. Cambridge: Polity. 
Bauman, Zygmunt [1992]. Intimations of Postmodernity. London: Routledge

Bauman, Zygmunt [2004]. Europe. An Unfinished Adventure. Cambridge: Polity.

Berger, Manfred [1990]. Jaruzelski: Traitor or Patriot? London: Hutchinson.

Hašek, Jaroslav [1997]. The Fateful Adventures of the Good Soldier Švejk, During the World War, Book One. Ist Books; originally published 1921-1923.

Main, Izabella [2004]. President of Poland or Stalin's most faithful pupil? The cult of Boleslaw Beirut in Stalinist Poland. In. Apor, Balázs, et al. (eds.). The Leadership Cult in Communist Dictatorships. Stalin and the Eastern Bloc. London: Palgrave Macmillan, pp. 179-193.

Morawski, Stefan [1998]. Bauman's way of seeing the world. Theory, Culture and Society 15: 29-38.

Smith, Dennis [1991]. The Rise of Historical Sociology. Cambridge: Polity.

Smith, Dennis [1998]. Zygmunt Bauman: How to be a successful outsider. Theory, Culture and Society 15: 39-45.

Smith, Dennis [1999]. Zygmunt Bauman. Prophet of Postmodernity. Cambridge: Polity.

Smith, Dennis [2000]. Norbert Elias and Modern Social Theory, London: Sage.

Smith, Dennis [2015]. Barrington Moore. In. International Encyclopedia of the Social and Behavioral Sciences. 2nd edition. London: Elsevier.

Thomas, William Isaac - Znaniecki, Florian [1918-1920]. The Polish Peasant in Europe and America. Boston: Richard G. Badger / The Gorham Press.

Wirth, Louis [1938]. Urbanism as a way of life. American Journal of Sociology 44: 1-24.

Dennis Smith (*1945) studied Modern History at Christ's College, Cambridge University followed by Sociology at the London School of Economics. He has taught at Leicester University, Aston University and Loughborough University as well as held visiting positions in, for example, Harvard (USA), Moscow Higher School of Economics (Russia), University of KwaZuluNatal (South Africa), and Shandong University in Jinan (China). He was editor of Current Sociology (journal of ISA) between 2002 and 2010, and previously of The Sociological Review (UK) between 1994 and 2001. His books include: The Rise of Historical Sociology (Polity 1991), Capitalist Democracy on Trial (Routledge 1990), Conflict and Compromise. Class Formation in English Society 1830-1914 (Routledge 1982), The Chicago School (Macmillan 1988) and Globalization. The Hidden Agenda (Polity 2006) as well as studies of Barrington Moore, Norbert Elias and Zygmunt Bauman. He is currently writing two books. One is a study of the EU, Brexit and the current transformation of the West. The other is a comparative study of the lives and careers of four famous prisoners: Oscar Wilde, Jean Améry, Nelson Mandela and Aung San Suu Kyi. Both books focus on the dynamics of forced socio-political displacement and the way people respond to the challenges this poses. 